\title{
Evaluation of an educational interven- tion for farming families to protect their children from pesticide exposure
}

T.M. Farahat, ${ }^{1}$ F.M. Farahat ${ }^{1}$ and A.A. Michael ${ }^{1}$

$$
\begin{aligned}
& \text { تقييم التدخلات التثقيفية لحماية الأطفال من التعرٌّ لمبيدات الموامّ في العائلات القاطنة في المناطق الزارعية } \\
& \text { تغريد محمد فرحات، فيصل مصطفى فرحات، عاطف عوضلات الثيفية ميخائيل }
\end{aligned}
$$

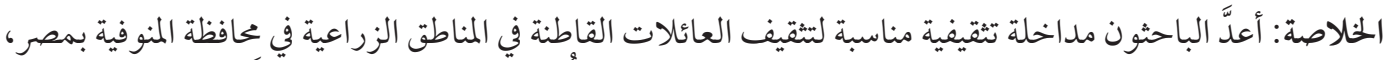

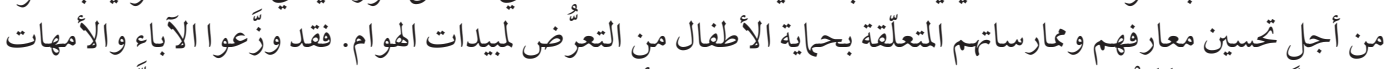

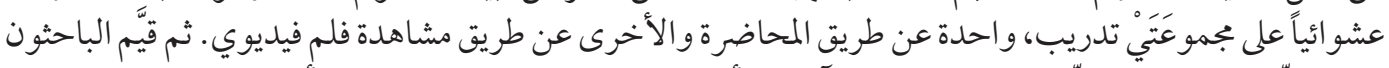

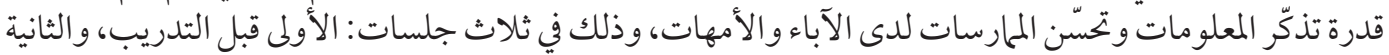

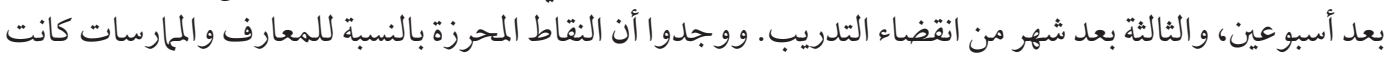

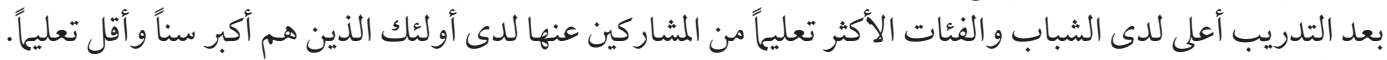

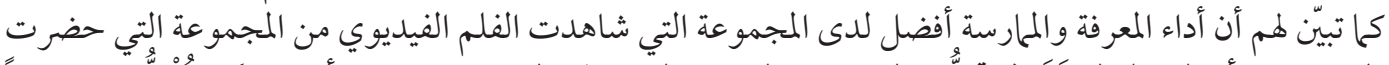

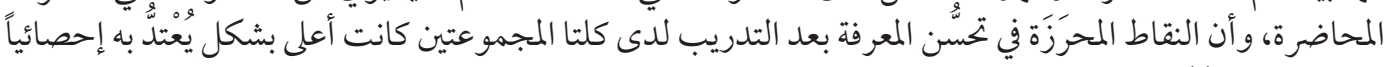
من النقاط المحرَزَة في الممارسة.

ABSTRACT A culturally appropriate educational intervention was developed and directed towards farming families in Menoufia governorate, Egypt, to improve their knowledge and practices in protecting their children from exposure to pesticides. Parents were randomly assigned to either a lecture or videotape training group. Ability to recall information or improve practices among parents was evaluated in 3 sessions: pretraining and 2 weeks and 1 month after training. Knowledge and practice scores after training of younger and more educated participants were significantly higher than older, less educated participants. Knowledge and practice performance of the videotape group was better than the lecture group and in both groups the improvement of knowledge scores after training was significantly higher than that of practice scores.

Évaluation d'une intervention éducative visant à aider les familles d'agriculteurs à protéger leurs enfants contre l'exposition aux pesticides

RÉSUMÉ Une intervention éducative culturellement adaptée a été mise au point à l'intention des familles d'agriculteurs du gouvernorat de Menoufia (Égypte) afin de leur permettre d'améliorer leurs connaissances et leurs pratiques en ce qui concerne la protection de leurs enfants contre l'exposition aux pesticides. Les parents ont été répartis de façon aléatoire dans deux groupes de formation, dont l'un a assisté à des cours magistraux et l'autre a visionné des vidéos. La capacité des parents à se souvenir des informations ou à améliorer leurs pratiques a été évaluée lors de trois sessions : avant la formation, deux semaines après, et un mois après. Les scores obtenus après la formation en matière de connaissances et de pratiques par les participants les plus jeunes et les plus instruits étaient significativement plus élevés que ceux obtenus par les participants plus âgés et moins instruits. Les résultats atteints en matière de connaissances et de pratiques par le groupe qui avait suivi la vidéoformation étaient supérieurs à ceux atteints par l'autre groupe, et dans les deux groupes, l'amélioration des scores relatifs aux connaissances après la formation était significativement plus importante que celle des scores relatifs aux pratiques.

${ }^{1}$ Department of Community Medicine and Environmental Health, Faculty of Medicine, University of Menoufia, Egypt (Correspondence to F.M. Farahat: fmfayssal@yahoo.com).

Received: 26/12/05; accepted: 28/08/06

المجلة الصحية لشرق المتوسط، منظمة الصحة العالمية، المجلد الخامس عشر، العدد (، 9 +. 


\section{Introduction}

In recent years there has been heightened concern over the potential impact of environmental exposure to chemicals on the health of children [1]. Pesticides represent one particular group of environmental contaminants to which children in agricultural communities are inequitably exposed [2].

Pesticides persist in dust when they are used around homes, and those used outdoors end up in soil and are brought into the house on shoes and pets. Pesticides in soil and dust in indoor environments persist longer than they do outside, where exposure to sun and rain helps to break down pesticide residues [3]. Children and infants can be particularly affected by pesticides because of their physiological immaturity and greater risk of exposure to pesticides. The difference in risk relates more to different levels of exposure than to toxicological vulnerability by age [4].

The work and living environments in agricultural communities in developing countries provide numerous sources of pesticide exposure. Keifer et al. categorized these sources as avoidable (e.g. diluting and mixing pesticides, applying pesticides, being sprayed), unavoidable (e.g. drifts, contact with residues) and unknown (e.g. contaminated water, contaminated fruits and vegetables) [5]. This pattern of exposure differs from those reported in other studies due to the relatively high level of exposure, lack of protective measures and lack of awareness by the population about the hazards and long-term effects of many pesticides used [6]. Farmers' housing can be a major source of contamination through proximity to sprayed fields and exposure to drifts during and following application of pesticides [7]. Farmers themselves may contaminate their homes by inadvertently carrying pesticides from work on their clothes, skin, hair, tools and vehicles [2].

Pesticides are widely used in agriculture in Egypt. Approximately 10000 to 60000 tons of pesticides are used annually in agriculture or for public health reasons [8]. Safety measures are generally poorly applied and the general population lacks proper knowledge about safe handling and hazards of these chemicals [9].

This study in Menoufia governorate in Egypt aimed to evaluate the effectiveness of culturally appropriate educational interventions directed towards farming families to protect their children from the hazards of pesticide exposure.

\section{Methods}

\section{Location and sample}

The study was conducted in 2 Egyptian villages (Ganzoor and Monsh'at Sultan, village 1 and village 2 respectively) located in Menoufia governorate, where agriculture is the main occupation. They were randomly selected from Menoufia villages that have family health centres. The family health centre ensures that every family in the village has a file to allow follow-up of the health of all family members. This study was conducted at the family health centre of each village. Each centre has a well-equipped training unit that includes 1 big room for health education, 4 small rooms for interview and a waiting hall and playground used for accompanying children.

A sample of 100 families registered at the family health centre from each village was randomly selected to participate in the study. Inclusion criteria were: living in homes among agricultural fields, having at least 1 preschool child (aged 4-6 years) and the family's main occupation being farming.

\section{Questionnaire design}

A questionnaire was designed and validated to assess the pesticide-related knowledge and practice of farmers. A pilot study was conducted to test the reliability of the ques- 
tionnaire. Irrelevant and difficult items were omitted or modified to be easily understood by participants with limited years of education.

The questionnaire included personal and family data, previous history of pesticide poisoning for any family member, attendance at any previous health education session on pesticide hazards, parents' perceived needs for future relevant education and parents' preferences for the education method.

Knowledge questions included items about different kinds of pesticides, routes of exposure, short- and long-term effects of pesticides on human health, vulnerability of children, methods of protecting themselves and their families from exposure (e.g. hand washing, separating work clothes, timing of entry after application), alternative methods to combat pests in the field and at home (e.g. keeping house clean, rapid disposal of waste, keeping food and drinks covered, using window screens).

Practice questions focused on frequency of pesticide use at home and on the farm, possible actions that could be taken by parents to reduce their children's exposure to pesticides whether at the home or farm (e.g. using minimal amount of pesticides and as needed only, keeping pesticides away from children, never allowing children to use pesticides, avoiding use of pesticides on children's bodies, keeping clothes and toys of children and food or drink away during pesticides application, teaching children to wash their hands before eating and after playing, washing all vegetables and fruits before eating, never using empty pesticide containers for any other purpose).

\section{Intervention}

The study was conducted on Thursdays (between 12.00 and 16.00 hours). It was carried out in 2 phases: village 1 (MarchJune 2004); village 2 (July-October 2004).
A total of 15 health education intervention sessions were implemented in each village, with about 10 participants per session.

The 2 villages were randomly assigned to either lecture (village 1) or video (village 2 ) training sessions. A lecture and a videotape on the hazards and safe use of pesticides were developed by the investigators specifically for the purpose of this study. Both parents were required to complete 3 consecutive educational sessions, 2 weeks and 1 month apart. Child care was provided for the accompanying children during the training of parents.

During the 1st session demographic and pre-training knowledge and practice questionnaires were administered individually through an interview to assist less welleducated participants. After completion of the questionnaires either a lecture or videotape session, according to the village, was provided to parents (about 10 participants per session). The lecture and videotape included the same information that was asked about in the pre-training questionnaire. They lasted for 30 minutes followed by 10 minutes discussion. All lectures and discussions were administered by the same investigator.

In the 2nd and 3rd sessions, participants were tested for their ability to recall information or change in practice after attending the lecture or watching the videotape. To measure change in knowledge and/or practice, an identical pre- and post-training questionnaire was used. Knowledge and practice scores were calculated for each participant. The maximum total knowledge score was 23 and total practice score was 15 .

\section{Statistical analysis}

Statistical analysis was done using SPSS, version 11.00. Student $t$-test was used to compare the means of the 2 groups. ANOVA test was used to compare knowledge

المجلة الصحية لشرق المتوسط، منظمة الصحة العالمية، المجلد الخامس عشر، العدد (،99.ب 
and practice scores in the consecutive sessions, followed by Student Newman-Keuls post hoc test for multiple comparisons. Chi-squared test with Yates continuity correction or Fisher exact test were used when appropriate. Level of significance was determined at $P$-value $\leq 0.05$.

The reliability of questionnaire items was tested by entering data from the pilot study and obtaining Cronbach alpha coefficients for knowledge and practice items. Cronbach alpha coefficients were 0.723 and 0.897 respectively.

\section{Results}

\section{Demographic characteristics}

Table 1 shows the demographic characteristics of the participating families. There were 100 mothers and 65 fathers from village 1 compared with 88 mothers and 44 fathers from village 2 who completed all 3 training sessions.

In both villages, the number of rooms in the houses of participating families ranged from 1-5 rooms with a mean of 2.8 (standard deviation 0.8). Water supply was either through wells $(48 \%)$, taps $(40 \%)$ or both (14\%). Only $10 \%$ of the houses had floors made of tiles, $40.5 \%$ were cement and $49.6 \%$ were mud. Most houses (94.0\%) had a room for domestic animals (e.g. cows, buffaloes, goats, sheep), either inside $(50.5 \%)$ or outside the home $(43.5 \%)$. Window screens were reported to be present in $55.5 \%$ of the houses.

All participating families were living in houses among agricultural fields and 78\% of the houses were near uncovered water channels.

\section{Parents' preference for the educational method}

None of the parents had received any previous education about pesticide exposure. Most of them $(81.6 \%)$ agreed that pesticide-related training programmes should be implemented

\begin{tabular}{lcc}
\hline \multicolumn{3}{l}{$\begin{array}{l}\text { Table 1 Demographic characteristics of } \\
\text { participating families }\end{array}$} \\
\hline Variable & $\begin{array}{c}\text { Lecture } \\
\text { group } \\
\text { Village 1 } \\
(\boldsymbol{n}=165)\end{array}$ & $\begin{array}{c}\text { Videotape } \\
\text { group } \\
\text { Village 2 } \\
(\boldsymbol{n}=132)\end{array}$ \\
\hline $\begin{array}{l}\text { Participating } \\
\text { individuals [No, (\%)] } \\
\quad \text { Mothers }\end{array}$ & $100(60.6)$ & $88(66.7)$ \\
$\quad$ Fathers & $65(39.4)$ & $44(33.3)$ \\
$\begin{array}{l}\text { Mean (SD) family } \\
\text { size (No.) }\end{array}$ & $4.42(1.1)$ & $4.93(0.9)$ \\
$\begin{array}{l}\text { Mean (SD) age of } \\
\text { parents (years) }\end{array}$ & $29.3(5.1)$ & $30.9(7.5)$ \\
$\begin{array}{l}\text { Parent's education } \\
\text { [No, (\%)] }\end{array}$ & & \\
$\begin{array}{l}\text { Illiterate or read and } \\
\text { write }\end{array}$ & $74(44.9)$ & $53(40.2)$ \\
$\begin{array}{l}\text { Secondary school or } \\
\text { higher }\end{array}$ & $91(55.2)$ & $79(59.9)$ \\
\hline
\end{tabular}

$\mathrm{n}=$ total number of participants.

each year (i.e. before the season for pesticide application to the cotton crop). Videotape was the preferred method of training for $63.5 \%$ of participants compared with $30.5 \%$ who preferred a lecture, while no preference was expressed by $6.0 \%$ of the participants.

\section{Pesticide application inside and outside homes}

All participating families were using pesticides at home and in the fields. Inside the home, most of the families $(80.5 \%)$ frequently applied pesticides (4-7 days/week) as compared to $19.5 \%$ with infrequent application (1-3 days/week). All families were using flying insect killers (main ingredients include tetramethrin, sumithrin, pyrethrin, piperonyl butoxide) in different forms, mainly mats $(94.6 \%)$ and aerosols $(55.5 \%) ; 28 \%$ were applying crawling insect killer powder (main ingredients include tetramethrin and malathion); 26\% were 
applying malathion on the hair of their children to protect them against hair lice; while $19 \%$ were occasionally using rodenticides for rats (Table 2).

In the fields, $37 \%$ of families were applying pesticides themselves and $63 \%$ hired workers to apply pesticides to their crops. Pesticides applied in the fields were organophosphates $(59.0 \%)$, carbamates $(40.5 \%)$ and pyrethroids (28.5\%) (Table 2). Pesticides were usually applied in the form of liquid sprayed using special back-held machines.

\section{Assessment of knowledge and practice among parents}

Knowledge and practice questions as well as the percentage of participants' responses are presented in Tables 3-5 for the 1st session (pre-training) and the 2nd and 3rd sessions ( 2 weeks and 1 month later). In both groups, the knowledge scores of par- ticipants improved significantly in the 2 nd and 3rd sessions, as compared to the pretraining session. Although the practice scores of both groups improved in subsequent sessions, the changes were not significant (Table 6). On the other hand, knowledge and practice scores did not show any significant differences between lecture and videotape groups in any of the sessions (Table 6). However, knowledge and practice performance of the videotape group was better in the 2nd and 3 rd sessions as compared to the lecture group. At the same time, in the lecture and videotape groups, the improvement of knowledge scores was significantly higher than that of practice scores.

The parents with high school or university degree showed significantly greater improvements in knowledge and practice than parents who were illiterate or only able to read and write (Table 7).

\begin{tabular}{|c|c|c|c|c|c|c|}
\hline \multirow[t]{2}{*}{ Variable } & \multicolumn{2}{|c|}{$\begin{array}{l}\text { Lecture group } \\
\quad(n=165)\end{array}$} & \multicolumn{2}{|c|}{$\begin{array}{l}\text { Videotape group } \\
\quad(n=132)\end{array}$} & \multicolumn{2}{|c|}{$\begin{array}{l}\text { Both groups } \\
(n=297)\end{array}$} \\
\hline & No. & $\%$ & No. & $\%$ & No. & $\%$ \\
\hline \multicolumn{7}{|l|}{ Frequency of pesticides use at home } \\
\hline Frequent (4-7 days/week) & 130 & 78.8 & 109 & 82.6 & 239 & 80.5 \\
\hline Infrequent (1-3 days/week) & 35 & 21.2 & 23 & 17.4 & 58 & 19.5 \\
\hline \multicolumn{7}{|l|}{ Pesticides used at home } \\
\hline \multicolumn{7}{|l|}{ Flying insect killers } \\
\hline Mats & 165 & 100.0 & 116 & 87.9 & 281 & 94.6 \\
\hline Aerosols & 94 & 57.0 & 71 & 53.8 & 165 & 55.5 \\
\hline Crawling insect killers powder & 50 & 30.3 & 32 & 24.2 & 82 & 27.5 \\
\hline Rodenticides (for rats) & 36 & 21.8 & 20 & 15.2 & 56 & 19.0 \\
\hline Head lice killers & 47 & 28.5 & 29 & 22.0 & 76 & 25.5 \\
\hline \multicolumn{7}{|l|}{ Pesticides used at farm } \\
\hline Organophosphate & 92 & 55.8 & 83 & 62.9 & 175 & 59.0 \\
\hline Carbamates & 78 & 47.3 & 42 & 31.8 & 120 & 40.5 \\
\hline Pyrethroids & 55 & 33.3 & 30 & 23.0 & 85 & 28.5 \\
\hline
\end{tabular}

$\mathrm{n}=$ total number of participants. 
Table 3 Comparison of knowledge of lecture and videotape groups regarding children's exposure to pesticides, pre-training, and 2 weeks and 1 month after the training

\begin{tabular}{|c|c|c|c|c|c|c|}
\hline \multirow[t]{3}{*}{ Knowledge } & \multicolumn{2}{|c|}{ Pre-training } & \multicolumn{2}{|c|}{2 weeks after } & \multicolumn{2}{|c|}{1 month after } \\
\hline & $\begin{array}{l}\text { Lecture } \\
(n=65)\end{array}$ & $\begin{array}{l}\text { Video } \\
(n=32)\end{array}$ & $\begin{array}{l}\text { Lecture } \\
(n=65)\end{array}$ & $\begin{array}{l}\text { Video } \\
(n=32)\end{array}$ & $\begin{array}{l}\text { Lecture } \\
(n=65)\end{array}$ & $\begin{array}{l}\text { Video } \\
(n=32)\end{array}$ \\
\hline & $\%$ & $\%$ & $\%$ & $\%$ & $\%$ & $\%$ \\
\hline \multicolumn{7}{|l|}{ Different types of pesticides } \\
\hline Know 4-6 types & 54.0 & 58.0 & 83.0 & 91.0 & 78.0 & 85.0 \\
\hline Know 2-3 types & 23.0 & 21.0 & 14.0 & 7.0 & 19.0 & 14.0 \\
\hline Know 1 type & 23.0 & 21.0 & 3.0 & 2.0 & 3.0 & 1.0 \\
\hline \multicolumn{7}{|l|}{ Route of exposure to pesticides } \\
\hline Inhalation & 64.0 & 68.0 & 91.0 & 94.0 & 89.0 & 93.0 \\
\hline Ingestion & 74.0 & 71.0 & 93.0 & 98.0 & 92.0 & 99.0 \\
\hline Dermal & 49.0 & 51.0 & 89.0 & 92.0 & 85.0 & 91.0 \\
\hline \multicolumn{7}{|l|}{$\begin{array}{l}\text { Children are more vulnerable to } \\
\text { pesticides toxicity: }\end{array}$} \\
\hline Agree & 74.0 & 78.0 & 100.0 & 100.0 & 100.0 & 100.0 \\
\hline Disagree & 26.0 & 22.0 & 0.0 & 0.0 & 0.0 & 0.0 \\
\hline \multicolumn{7}{|l|}{$\begin{array}{l}\text { Health effects of pesticides on } \\
\text { children include: }\end{array}$} \\
\hline Chest allergy & 76.0 & 76.0 & 90.0 & 92.0 & 89.0 & 92.0 \\
\hline Skin allergy & 73.0 & 74.0 & 88.0 & 92.0 & 90.0 & 90.0 \\
\hline Hepatotoxicity & 58.0 & 55.0 & 87.0 & 96.0 & 85.0 & 91.0 \\
\hline Cancer & 56.0 & 60.0 & 83.0 & 94.0 & 82.0 & 90.0 \\
\hline Nephrotoxicity & 50.0 & 55.0 & 86.0 & 91.0 & 86.0 & 88.0 \\
\hline Decrease child attention & 44.0 & 41.0 & 79.0 & 83.0 & 74.0 & 80.0 \\
\hline Decrease child memory & 36.0 & 38.0 & 75.0 & 83.0 & 73.0 & 80.0 \\
\hline Decrease child intelligence & 40.0 & 42.0 & 85.0 & 82.0 & 81.0 & 79.0 \\
\hline \multicolumn{7}{|l|}{$\begin{array}{l}\text { Alternate methods to minimize } \\
\text { use of pesticides at home }\end{array}$} \\
\hline Keep house clean & 75.0 & 77.0 & 100.0 & 100.0 & 100.0 & 100.0 \\
\hline Rapid disposal of wastes & 56.0 & 53.0 & 90.0 & 95.0 & 86.0 & 93.0 \\
\hline Keep food and drinks covered & 69.0 & 66.0 & 89.0 & 100.0 & 90.0 & 100.0 \\
\hline Use of window screen & 58.0 & 61.0 & 95.0 & 100.0 & 95.0 & 100.0 \\
\hline \multicolumn{7}{|l|}{$\begin{array}{l}\text { Alternate methods to minimize } \\
\text { use of pesticides at farm }\end{array}$} \\
\hline Continuous cleaning of plants & 64.0 & 62.0 & 76.0 & 82.0 & 74.0 & 80.0 \\
\hline Proper disposal of wastes & 45.0 & 47.0 & 79.0 & 87.0 & 75.0 & 87.0 \\
\hline Use of natural methods & 38.0 & 42.0 & 68.0 & 89.0 & 65.0 & 85.0 \\
\hline $\begin{array}{l}\text { Consult the agricultural } \\
\text { authorities }\end{array}$ & 26.0 & 24.0 & 65.0 & 83.0 & 61.0 & 79.0 \\
\hline
\end{tabular}

$\mathrm{n}=$ total number of participants. 
Table 4 Comparison of practices of lecture and videotape groups to reduce exposure of their children to pesticides at home, pre-training, and 2 weeks and 1 month after the training

\begin{tabular}{|c|c|c|c|c|c|c|}
\hline \multirow[t]{4}{*}{ Practice } & \multicolumn{2}{|c|}{ Pre-training } & \multicolumn{2}{|c|}{2 weeks after } & \multicolumn{2}{|c|}{1 month after } \\
\hline & Lecture & Video & Lecture & Video & Lecture & Video \\
\hline & $(n=165)$ & $(n=132)$ & $(n=165)$ & $(n=132)$ & $(n=165)$ & $(n=132)$ \\
\hline & $\%$ & $\%$ & $\%$ & $\%$ & $\%$ & $\%$ \\
\hline Apply pesticides as needed only & 41.0 & 43.0 & 81.0 & 88.0 & 79.0 & 92.0 \\
\hline \multicolumn{7}{|l|}{ Avoid use of pesticides on } \\
\hline children’s bodies & 83.0 & 82.0 & 99.0 & 97.0 & 99.0 & 97.0 \\
\hline \multicolumn{7}{|l|}{ Never allow children to use } \\
\hline pesticides & 61.0 & 63.0 & 92.0 & 95.0 & 91.0 & 96.0 \\
\hline \multicolumn{7}{|l|}{ Keep children's clothes and toys } \\
\hline away during pesticide application & 43.0 & 40.0 & 92.0 & 94.0 & 90.0 & 93.0 \\
\hline \multicolumn{7}{|l|}{ Keep food and drinks away during } \\
\hline pesticide application & 76.0 & 78.0 & 94.0 & 94.0 & 93.0 & 95.0 \\
\hline \multicolumn{7}{|l|}{ Teach children to wash hands } \\
\hline before eating and after playing & 58.0 & 56.0 & 87.0 & 92.0 & 85.0 & 90.0 \\
\hline \multicolumn{7}{|l|}{ Wash vegetables and fruits before } \\
\hline eating & 89.0 & 88.0 & 99.0 & 99.0 & 100.0 & 100.0 \\
\hline \multicolumn{7}{|l|}{ Never use empty pesticide } \\
\hline containers in other purposes & 69.0 & 71.0 & 89.0 & 96.0 & 85.0 & 95.0 \\
\hline Keep pesticides away from children & 54.0 & 64.0 & 90.0 & 92.0 & 88.0 & 89.0 \\
\hline
\end{tabular}

$\mathrm{n}=$ total number of participants.

Following training, about $60 \%$ of the participants reported that they could completely stop the use of pesticides inside the home in comparison with $30 \%$ before the educational programme. However, none thought that they could completely stop the use of pesticides in the fields. Of participating mothers, $5 \%$ and $8 \%$ (in the lecture and videotape groups respectively) mentioned that they had already stopped the application of pesticides inside their homes completely after the education intervention.

\section{Discussion}

The main objective of health education programmes is to change knowledge and consequently practices [10]. Researchers usually assess only the immediate change in knowledge after implementation of educational interventions. The current study was conducted to measure the immediate change as well as the sustainability of information gained after implementation of 2 different and commonly used educational interventions (lecture and videotape).

Both knowledge and practice of agricultural families were assessed and followed up for 2 consecutive sessions, 2 weeks and 1 month apart. Most participants lacked sound knowledge and proper practice about handling of pesticides, whether at home or at the farm. This may be attributed to the absence or deficiency of health education programmes directed towards those

المجلة الصحية لشرق المتوسط، منظمة الصحة العالمية، المجلد الخامس عشر، العدد (، 9 ·. 
Table 5 Comparison of practices of lecture and videotape groups to reduce exposure of their children to pesticides at the farm, pre-training, and 2 weeks and 1 month after the training

\begin{tabular}{|c|c|c|c|c|c|c|}
\hline \multirow[t]{2}{*}{ Practice } & \multicolumn{2}{|c|}{ Pre-training } & \multicolumn{2}{|c|}{2 weeks after } & \multicolumn{2}{|c|}{1 month after } \\
\hline & $\begin{array}{c}\text { Lecture } \\
(n=165) \\
\%\end{array}$ & $\begin{array}{c}\text { Video } \\
(n=132) \\
\%\end{array}$ & $\begin{array}{c}\text { Lecture } \\
\left(\begin{array}{c}n=165) \\
\%\end{array}\right.\end{array}$ & $\begin{array}{c}\text { Video } \\
(n=132) \\
\%\end{array}$ & $\begin{array}{c}\text { Lecture } \\
(n=165) \\
\%\end{array}$ & $\begin{array}{c}\text { Video } \\
(n=132) \\
\%\end{array}$ \\
\hline $\begin{array}{l}\text { Close house windows and } \\
\text { doors during application } \\
\text { in nearby farm }\end{array}$ & 44.0 & 42.0 & 80.0 & 86.0 & 76.0 & 82.0 \\
\hline $\begin{array}{l}\text { Never allow children in the field } \\
\text { during spraying }\end{array}$ & 38.0 & 42.0 & 98.0 & 98.0 & 95.0 & 96.0 \\
\hline $\begin{array}{l}\text { Never allow household utensils } \\
\text { to be used in diluting, mixing or } \\
\text { application of pesticides }\end{array}$ & 66.0 & 77.0 & 100.0 & 100.0 & 100.0 & 100.0 \\
\hline $\begin{array}{l}\text { Father's contaminated clothes } \\
\text { kept away from house }\end{array}$ & 34.0 & 41.0 & 91.0 & 95.0 & 88.0 & 95.0 \\
\hline $\begin{array}{l}\text { Father showers after use of } \\
\text { pesticides in the farm }\end{array}$ & 57.0 & 51.0 & 71.0 & 72.0 & 74.0 & 71.0 \\
\hline $\begin{array}{l}\text { Dispose of empty containers in a } \\
\text { safe place }\end{array}$ & 74.0 & 77.0 & 89.0 & 91.0 & 91.0 & 92.0 \\
\hline
\end{tabular}

$\mathrm{n}=$ total number of participants.

Table 6 Mean knowledge score of the lecture and videotape groups, pre-training, and 2 weeks and 1 month after the training

\begin{tabular}{lccc}
\hline Performance & $\begin{array}{c}\text { Lecture group }(\boldsymbol{n}=\mathbf{1 6 5}) \\
\text { Mean (SD) score }\end{array}$ & $\begin{array}{c}\text { Videotape group }(\boldsymbol{n}=132) \\
\text { Mean (SD) score }\end{array}$ & $\boldsymbol{P}$-value \\
\hline Knowledge & $14.20(4.17)$ & $14.04(2.78)$ & $>0.05$ \\
$\quad$ Pre-training & $21.10(4.30)^{\mathrm{b}}$ & $22.60(4.20)^{\mathrm{b}}$ & $>0.05$ \\
2 weeks after & $20.18(4.90)^{\mathrm{b}}$ & $21.30(4.80)^{\mathrm{b}}$ & $>0.05$ \\
1 month after & $<0.001$ & $<0.001$ & \\
$\quad P$-value & & & \\
Practice & $9.32(4.22)$ & $9.05(4.05)$ & $>0.05$ \\
$\quad$ Pre-training & $10.82(3.96)$ & $11.20(3.25)$ & $>0.05$ \\
2 weeks after & $10.52(3.45)$ & $11.01(3.47)$ & $>0.05$ \\
1 month after & $>0.05$ & $>0.05$ & \\
$P$-value $^{\mathrm{a}}$ & & & \\
\hline
\end{tabular}

${ }^{a}$ ANOVA test. $\quad{ }^{\mathrm{b}}$ Significant compared to pre-training $(\mathrm{P}<0.05)$.

$\mathrm{n}=$ total number of participants; $S D=$ standard deviation.

high-risk groups in Egypt or because these programmes are improperly presented. Amr stated that the adverse effects of pesticide exposure in Egypt are due to lack of proper knowledge of safe handling of pesticides and that safety measures are generally 
Table 7 Mean knowledge and practice scores of the lecture and videotape groups according to level of education, pre-training, and 2 weeks and 1 month after the training

\begin{tabular}{|c|c|c|c|c|c|c|}
\hline \multirow[t]{3}{*}{ Performance } & \multicolumn{3}{|c|}{ Lecture group } & \multicolumn{3}{|c|}{ Videotape group } \\
\hline & $\begin{array}{l}\text { Illiterate/read } \\
\text { and write } \\
(n=74)\end{array}$ & $\begin{array}{c}\text { High school/ } \\
\text { university } \\
(n=91)\end{array}$ & $P$-value & $\begin{array}{l}\text { Illiterate/read } \\
\text { and write } \\
(n=53)\end{array}$ & $\begin{array}{c}\text { High school/ } \\
\text { university } \\
(n=79)\end{array}$ & $P$-value \\
\hline & $\begin{array}{l}\text { Mean (SD) } \\
\text { score }\end{array}$ & $\begin{array}{l}\text { Mean (SD) } \\
\text { score }\end{array}$ & & $\begin{array}{l}\text { Mean (SD) } \\
\text { score }\end{array}$ & $\begin{array}{l}\text { Mean (SD) } \\
\text { score }\end{array}$ & \\
\hline \multicolumn{7}{|l|}{ Knowledge } \\
\hline Pre-training & $13.90(1.50)$ & $14.50(2.90)$ & $>0.05$ & 13.65 (1.63) & $14.31(2.84)$ & $>0.05$ \\
\hline 2 weeks after & $20.00(1.90)$ & $23.10(2.26)$ & $<0.001$ & $20.25(1.84)$ & $23.31(2.74)$ & $<0.001$ \\
\hline 1 month after & $19.10(1.70)$ & $22.00(2.88)$ & $<0.001$ & $19.36(1.87)$ & $22.53(2.81)$ & $<0.001$ \\
\hline \multicolumn{7}{|l|}{ Practice } \\
\hline Pre-training & $8.99(1.30)$ & $9.67(3.24)$ & $>0.05$ & $8.77(1.61)$ & $9.65(3.70)$ & $>0.05$ \\
\hline 2 weeks after & $9.88(2.10)$ & $11.76(1.88)$ & $<0.001$ & $9.91(2.32)$ & $11.93(2.30)$ & $<0.001$ \\
\hline 1 month after & $9.37(2.30)$ & $11.67(1.50)$ & $<0.001$ & $9.74(2.21)$ & $11.84(2.20)$ & $<0.001$ \\
\hline
\end{tabular}

$\mathrm{n}=$ total number of participants; $S D=$ standard deviation.

poorly applied by both the general public and pesticide workers [9].

Changing behaviour is usually more difficult although it may be more sustainable than knowledge [11]. Using non-traditional appropriately designed programmes that depend more on visual memory is more likely to ensure sustainability of the knowledge gained as well as changes in practice [12]. Visual memory is rapidly acquired and longer-standing than auditory memory [13].

In the current study, after implementation of educational intervention programmes (lecture and videotape), there was an immediate and sustained improvement in the knowledge and practice of families. However, knowledge showed a significantly greater improvement than practice. There are many factors that could affect knowledge gain and behaviour modification. The most important are age, educational level and cultural appropriateness of the educational intervention [10]. In the current study, the lecture and videotape were prepared to include information from the same environment where participants were living. However, the videotape was more culturally appropriate as it included pictures and movies that showed the right and wrong practices and was designed and prepared inside homes and in the fields of the participants.

Moreover, about $43 \%$ of participants were illiterate or only able to read and write, so videotapes with pictures and movies would ensure sustainability of gained knowledge. At the same, well-educated parents were better able to acquire information and change their behaviour than less educated parents.

The mean age of the participants was around 30 years, which may be an appropriate age for knowledge gain but is not the most appropriate age for behaviour modification. This raises the issue of implementing pesticide educational intervention programmes as early as possible because younger people are more likely to retain the knowledge and change their practices $[14,15]$. 


\section{Conclusion}

Pesticides represent a major environmental hazard. The toxic effects of pesticides are a concern among high-risk groups, especially children. Development of culturally appropriate educational intervention programmes is essential to protect the children of farming families from the hazards of pesticide exposure. Video training is better than lectures in assuring knowledge gain and probably enhancing retention. Knowledge is easier to change than practice, which requires continuous education and a supportive environment.

\section{Acknowledgements}

This article was supported in part by grant EMRO/RPC/ TSA 03/102 from the Research and Policy Cooperation, World Health Organization Regional Office for the Eastern Mediterranean.

\section{References}

1. Mott L. The disproportionate impact of environmental health threats on children. Environmental health perspectives, 1993, 6:33-5.

2. Ecobichon DJ. Occupational hazards of pesticide exposure. Philadelphia, Taylor and Francis, 1999:209-27.

3. Simcox NJ et al. Pesticides in household dust and soil: exposure pathways for children of agricultural families. Environmental health perspectives, 1995, 103:1126-34.

4. Healthy environments for children. Initiating an alliance for action. Geneva, World Health Organization, 2002.

5. Keifer $\mathrm{M}$ et al. Symptoms and cholinesterase activity among rural residents living near cotton fields in Nicaragua. Occupational and environmental medicine, 1996, 53:726-9.

6. Rosenstock L et al. Chronic central nervous system effects of acute organophosphate pesticide intoxication. The Pesticide Health Effects Study Group. Lancet, 1991, 338:223-7.

7. McCauley L. Reducing pesticide exposure in minority families. Research Triangle Park, North Carolina, United States Environmental Protection Agency, 2001.
8. Farahat TM et al. Neurobehavioural effects among workers occupationally exposed to organophosphorous pesticides. Occupational and environmental medicine, 2003, 60:279-86.

9. Amr MM. Pesticide monitoring and its health problems in Egypt, a third world country. Toxicology letters, 1999, 107:1-13.

10. Education for health. A manual on health education in primary health care. Geneva, World Health Organization, 1988:22-3.

11. Spreen O, Strauss E. A compendium of neuropsychological tests: administration, norms, and commentary, 2nd ed. Oxford, Oxford University Press, 1998.

12. Coults LC, Hardy LK. Teaching for health, 1st ed. London, Churchill Livingstone, 1985.

13. Lezak MD. Neuropsychological assessment, 3rd ed. Oxford, Oxford University Press, 1995:335-44.

14. Caldwell JC. Maternal education as a factor in child mortality. World health forum, 1981, 2(1):75-8.

15. Steen W, Bond A, Mage D. Agricultural health study-exposure pilot study report. Research Triangle Park, North Carolina, United States Environmental Protection Agency, 1997. 